\title{
Competition of maize hybrids with alexandergrass (Urochloa plantaginea)
}

\author{
Fernando Frandoloso ${ }^{1}$, Leandro Galon ${ }^{1}$, Ricardo Luis Gabiatti ${ }^{1}$, Felipe Bianchessi ${ }^{1}$, Cinthia Maethê Holz ${ }^{1}$, \\ André Dalponte Menegat ${ }^{1}$, Carlos Orestes Santin ${ }^{1}$, Francisco Wilson Reichert Júnior ${ }^{2}$, Milena Barretta \\ Franceschetti ${ }^{1}$, Maico André Michelon Bagnara ${ }^{1}$, Luciane Renata Agazzi ${ }^{3}$, César Tiago Forte ${ }^{4 *}$
}

\author{
${ }^{1}$ Agronomy Department, The Federal University of Fronteira Sul - UFFS, Campus Erechim, Rio Grande do Sul, Brazil, \\ CEP: 99700-000. \\ ${ }^{2}$ Agronomy Department, The Federal University of Santa Catarina - UFSC, Florianópolis, Santa Catarina, Brazil, CEP: \\ 88.040-900. \\ ${ }^{3}$ Agronomy Department, The Federal University of Viçosa - UFV, Viçosa, Minas Gerais, Brazil, CEP: 36570-900. \\ ${ }^{4}$ Agronomy Department, The Federal University of Santa Maria - UFSM, Campus Santa Maria, Rio Grande do Sul, \\ Brazil, CEP: 97105-900.
}

\section{* Corresponding author: cesartiagoforte@hotmail.com}

\begin{abstract}
Maize is one of the world's major cereals, and alexandergrass is the most damaging weed in the crop. The objective of this work was to evaluate the relative competitive ability of maize hybrids in the presence of alexandergrass through replacement series experiments. The experiments were set up in a complete randomized block design, with four replications. Firstly, for the maize hybrids as well as for the alexandergrass, the plant population was determined in which the final production becomes constant. were composed of plastic pots with a capacity of $8 \mathrm{dm} 3$, and in each experimental unit was placed in the proportion corresponding to each treatment (100: 00, 75:25, 50:50, 25:75 and 0:100) in each experimental unit, the species competing or not between them. For each hybrid, a separate experiment was considered with the objective of evaluating intra and interspecific competition. The analysis of the competitiveness of the species was carried out through diagrams applied to the replacement experiments and by the relative competitiveness indexes. At 50 days after the emergence of the maize the leaf area (LA) and the dry mass of the aerial part (DM) of the plants were checked. The relative competition was occured among the weed and each maize hybrid, being negatively affected for both of species, independently of the proportion of weed causing reductions in LA and DM of the maize. Interspecific competition causes less damage to LA and DM of species than intraspecific competition. There is basically competition for the same environment resources (water, $\mathrm{CO} 2$, sun light and nutrients) between maize and alexandergrass, being the crop more competitive than the weed.
\end{abstract}

Keywords: Zea mays, Urochloa plantaginea, Competitive ability.

Introduction

Maize (Zea mays L.) is one of the main cereals cultivated in the world, with Brazil being the third largest producer (USDA, 2018). The southern region accounts for $22.25 \%$ of the national production, with about 3.81 million hectares produced in the first and second seasons (CONAB, 2018), destined for grains to several industries, including food products for humans and animals (Faria et al., 2014). These facts demonstrate the importance of the maize crop for the southern region of Brazil, especially as it makes up the productive matrix of family units and contributes to the food security of the properties.

The productivity of maize crops can be influenced by several factors, among which weed infestation stands out, as they compete with the crop for the resources available in the environment, such as water, light and nutrients, difficult the management and are also hosts of pests and diseases that may attack the crop (Vidal and Merotto, 2010, Monquero,
2014) Weeds cause losses in grain yield of maize and also in the quality of harvested grains (Brito et al., 2011), which can reach $70 \%$ if no management method is adopted (Moraes et al., 2013).

Among the weeds that infest maize, alexandergrass ( $U$. plantaginea) stands out as one of the species that cause the most damage to crops, due to the high competitive ability caused by shading, absorb high amounts of water and nutrients, and produces a high number of seeds (Kissman and Groth, 1999; Velho et al., 2012; Wandscheer et al., 2013) and present C4-type metabolism. The C4 plants have higher ability to take advantage of the resources available in the environment and, therefore, are usually more competitive than the C3 plants (Wang et al, 2018).

In this sense, knowing the competitive ability of maize hybrids in relation to weeds becomes an important tool for the development of management strategies. Considering 
that in the crops, the population of the cultivated plants is generally constant, whereas the population of the weeds varies according to the seed bank of the soil and with the environmental conditions that change the level of infestation and consequent the competitiveness of the species (Galon et al., 2011; Agostinetto et al., 2013; Wandscheer et al., 2014). Thus, in competition studies, it is not enough to evaluate only the plant population in the competitive process, but also the influence of the variation in the proportion between the species (Christoffoleti and Victória Filho, 1996).

The determination of the competitive interactions for crops and weeds requires appropriate experimental designs and methods of analysis, with conventional replacement experiments being the most used to clarify such relationships (Vida et al., 2006; Agostinetto et al., 2013; Wandscheer et al., 2014, Forte et al., 2017). In these experiments, crops generally reach higher competitive ability than weeds. In the field, the effect of the weed on the crop is mainly due to the level of infestation and not to its individual competitive ability (Vilá et al., 2004). However, when there is competition between individuals of the same genus and/or species, the competitive advantage of the crop may be altered, since both exploit the same ecological niche. Thus, studies that show the variation in the proportion between the weeds and the crop to develop management strategies become relevant, starting from the possibility of defining the characteristics that confer greater competitive ability to the crops (Fleck et al., 2008; Galon et al., 2011; Agostinetto et al., 2013; Wandscheer et al., 2014; Forte et al., 2017).

The hypothesis of the work is that the maize hybrids present differentiation in the competition with the alexandergrass. The objective of this study was to evaluate the relative competitive ability of maize hybrids in the presence of alexandergrass through replacement series experiments.

\section{Results and Discussion}

The variance analysis of the data showed that there was a significant interaction between the leaf area (LA) and shoot dry matter (DM) proportions of maize hybrids and alexandergrass. Replacement experiments between maize versus maize hybrids indicated competition among species, where productivity values obtained in the different proportions between the two species deviated from the expected yield line. In general, the association between the two species was more damaging to the weed than the crop (Figures 1 and 2; Tables 1, 2 and 3).

\section{Productivity or relative variations}

The graphical results indicate that the maize hybrids (Agroeste, Morgan, Nidera and Syngenta) showed similarities regarding competition with the alexandergrass biotype and that differences were observed for the variables LA and DM, in the great majority of evaluated plant proportions (Figures 1 and 2, Table 1). Significant differences were observed in at least two proportions in relation to TRP for LA and DM of the hybrids Agroeste, Morgan, Nidera and Syngenta when competing with the alexandergrass, with concave lines in most situations and average values lower than 1 (Figures 1 and 2. Table 1). It should be noted that in only two situations the TRP presented values greater than 1 and convex line, for the variable DM in the proportions of 50:50 and 25:75 involving the Agroeste hybrid and the alexandergrass (Figure 2 and Table 1), but without significance in at least two proportions of evaluated plants.

These results of the TRP of concave lines and values lower than 1 , allow to infer that there was competition between maize and alexandergrass by the same environment resources. According to Rubin et al. (2014) when TRP $<1$ there is a mutual antagonism between species that are competing for the environment resources, not adding to the increase in final productivity. Results like the present study were found by Wandscheer et al. (2014) when evaluating the competitive ability of the DKB 240 YG maize hybrid in competition with different populations of Sudan grass (Sorghum sudanense).

For the variables LA and DM, we observed in all combinations of plants involving the maize hybrids and the alexandergrass that the deviations of the RP straight lines in relation to the expected lines are concave lines. For the same variable (DM) in the proportion of 75:25 involving the hybrid Nidera versus alexandergrass which also presented convex line, that is, when the lines are convex, loss of productivity occurs for both the crop and the competing species. Thus it is concluded that the competition was for the same resources of the environment. This demonstrates that the crop and the weed compete for the same resources of the environment in which they are inserted with mutual injury to the growth of the species. In order to study the effect of Sudan grass in maize (Wandscheer et al., 2014), ryegrass on barley (Galon et al., 2011) and soybean weeds (Forte et al., 2017) of concave lines for the crop and competitor for the evaluated variables, which corroborates that found in the present study.

Evaluating Figures 1 and 2, it was generally found that in all proportions there was a decrease in the LA and DM variables according to the increase in the population of the alexandergrass. In the LA (Figure 1) in the same population of the crop with the competitor (50:50) there was a significant difference, with reductions greater than 25.4; 33.0; 53.5 and $53.8 \%$ for the hybrids Agroeste, Morgan, Nidera and Syngenta, respectively, when compared to the free alexandergrass control.

For DM (Figure 2) using the same comparison, a decrease of 52.7; 13.6 and $37.6 \%$ for three hybrids; Agroeste AS1551 PRO2, Morgan MG300PW and Nidera NS92 PRO in coexistence with alexandergrass was observed. A curious fact was the competition of the Syngenta hybrid Velox TL that presented a $27 \%$ increase in DM when competing with the alexandergrass in the proportion of 50:50. This fact is explained by the fact that the hybrid has some intrinsic characteristic that maes it more competitive than the weed under study, such as a greater increase of leaf area and stem growth in the presence of the weed. Similar results were found by Wandscheer et al. (2014), where, when comparing combinations of maize (DKB 240 YG hybrid) and Sudan grass (Sorghum sudanense) plants, in proportions 100, 75, 50, 25 and $0 \%$ of maize plants and the inverse for the weed showed no significant reductions in any of the tested species. This fact can be explained by the plasticity of the species in responding to the variations in the availability of environment resources, that is, rapid morphological adjustments in response to the scarcity of resources, thus 
facilitating the capture of water, light, nutrients and space by the plant, making it more competitive (Dias-Filho, 2006).

This shows that the alexandergrass is very competitive and when it presents the same population that, the crop it causes negative interference in the maize growth, except to the Syngenta hybrid for the DM that showed contrary behavior as previously reported. According to Jannink et al., (2000) plant species when living in a community can respond to competition with reduced growth due to the effect of interference between them, which corroborates the observed in the present study with the negative effect on the LA and DM of most of the maize hybrids evaluated.

In general, maize hybrids presented higher relative growth than alexandergrass in all proportions of plants evaluated for the tested variables, presenting higher RP for the crop and smaller for the weed, however they presented little contribution to the TRP (Figures 1 and 2. Table 1). It is possible to report that the probable cause of maize has a higher relative growth than the alexandergrass is related to the stature of plants, becoming more efficient in the search for solar radiation and imposing shading to the weed (Almeida and Mundstock, 2001). When one species is more competitive than another it will indicate that it will have a greater ability to assimilate the resources available in the environment and thus increase growth and development potential, which increases the damage to the competitor, since smaller amounts of resources will be available (Agostinetto et al., 2013). In this way the competition for quantity and quality of light is the result of the proximity of plants, which compromises the increase of LA and DM, as there is interference in the formation and growth of leaves (Wu et al., 2012). It should be emphasized that in replacement experiments there is little evidence of qualitative changes due to population growth, that is, the dominance of one species over another rarely changes with population change (Cousens and O'Neill 1993).

The results showed, in general, higher TRP values of all combinations, the larger the proportions of maize plants in the simulations and the smaller the alexandergrass when competing with each other - a significant situation for both variables studied (Table 1 ). This behavior shows that the species are competitive and that one does not contribute more than expected to the total productivity of the other (Radosevich, 1987). Because they belong to the same botanical family, maize hybrids and alexandergrass were expected to exploit the same ecological niche and compete for the same environmental resources, presenting differences in competitiveness. These were verified in related species, such as between rice and red rice (Panton and Baker, 1991; Fleck et al., 2008), barley x ryegrass (Galon et al., 2011), rice $x$ gulf cockspur grass (Galon and Agostinetto, 2009) and sorghum crop $x$ Sorghum Halepense (Hoffman and Buhler, 2002).

It was observed that the morphological variables, LA and DM, of the maize hybrids; Agroeste, Morgan, Nidera and Syngenta, were reduced when they competed with alexandergrass in all combinations analyzed, regardless of the proportion of plants in the association (Table 2). The higher the proportion of the competitor in the association with the hybrids, the greater the damage to the crop variables. In the alexandergrass, the same tendency of reduction of the LA and the DM was observed. Research has reported that damage to crop and weed growth may occur when competing in a particular community (Fleck et al., 2008; Rigoli et al., 2008; Galon and Agostinetto, 2009; Agostinetto et al., 2009; Galon et al., 2011; Forte et al., 2017).

It was observed for the LA and DM variables that the highest averages per plant of the crop or even of the alexandergrass were obtained when they were presented in smaller populations in the association in all the combinations (Table 2). In this way it was found that interspecific competition is less harmful for both species involved than intraspecific competition. Christoffoleti and Victoria Filho (1996) also observed that the effect of intraspecific competition was more damaging than interspecific when working with maize in the presence of Amaranthus spp.. Zanine and Santos (2004) describe that the reduction in species growth, involved in intra-or interspecific combinations, results from spatial competition between groups of plants occupying the same space. Other studies involving different species of competing plants also showed effects similar to those observed in the present study, such as wheat in the presence of ryegrass (Rigoli et al., 2008), rice in competition with gulf cockspur grass (Galon and Agostinetto, 2009), rice and soybean $x$ southern crabgrass (Agostinetto et al., 2013), wheat $x$ turnip (Costa and Rizzardi, 2015) and soybean $x$ weeds (Forte et al., 2017).

Bianchi et al., (2006) describe that the competition affects quantitative and qualitative production, since it modifies the efficiency of the use of the resources of the environment, such as water, light, $\mathrm{CO} 2$ and nutrients, being established between the crop and the plants of other species on the site. This competition also occurs between individuals of the same species or between predominant biotypes in the area, as verified by Ferreira et al. (2008), which verified that ryegrass biotypes resistant to glyphosate have less competitive capacity than susceptible ones. It is also worth noting that in a plant community there is a benefit in the competition for the resources by those who establish themselves first, due to the intrinsic characteristics of each cultivar or hybrid as regards the competitive ability (root system, height, leaf area index, speed of growth, number of tiller, among others), by the best use or necessity of the resources by a certain species within an ecological niche.

\section{Competitive indexes}

The maize hybridity X (Agroeste - AS 1551 PRO 2, Morgan MG 300 PW, Nidera - NS 92 PRO and Syngenta - Velox TL) is more competitive than the alexandergrass $Y$, when compared by the coefficients developed by Hoffman and Buhler (2002), CR> 1, $K_{x}>K_{y}$ and $A>0$. Thus, a criterion to prove competitive superiority was adopted, the occurrence of a significant difference in at least two of these indices (Bianchi et al., 2006). In all simulations the maize hybrids presented the highest growth, for the variables LA and DM when in competition with the alexandergrass, as indicated by the CR index (greater than 1), $\mathrm{K}$ of the crop larger than that of the weed and A (positive), except for the Agroeste DM, which showed lower maize competitiveness (but with no 
Table 1. Relative differences for leaf area and dry matter of maize hybrids (Agroeste - AS 1551 PRO 2, Morgan - MG 300 PW, Nidera - NS 92 PRO and Syngenta - Velox TL) or alexandergrass (Urochloa plantaginea), 50 days after the emergency.

\begin{tabular}{lccc}
\hline \multirow{2}{*}{ Variables } & \multicolumn{2}{c}{ Associated plants proportions (maize: alexandergrass) } \\
\cline { 2 - 4 } AS 1551 PRO 2 & $75: 25$ & $50: 50$ & $25: 75$ \\
\cline { 2 - 4 } Alexandergrass & $-0.14( \pm 0.05)$ & $-0.13( \pm 0.02)^{*}$ & $-0.20( \pm 0.01)^{*}$ \\
Total & $-0.24( \pm 0.001)^{*}$ & $-0.37( \pm 0.03)^{*}$ & $-0.44( \pm 0.17)$ \\
\hline MG 300 PW & $0.62( \pm 0.06)^{*}$ & $0.51( \pm 0.04)^{*}$ & $0.37( \pm 0.18)$ \\
Alexandergrass & $-0.27( \pm 0.03)^{*}$ & $-0.17( \pm 0.05)$ & $-0.14( \pm 0.01)^{*}$ \\
Total & $-0.23( \pm 0.001)^{*}$ & $-0.45( \pm 0.001)^{*}$ & $-0.53( \pm 0.001)^{*}$ \\
\hline NS 92 PRO & $0.50( \pm 0.03)^{*}$ & $0.39( \pm 0.05)^{*}$ & $0.33( \pm 0.01)^{*}$ \\
Alexandergrass & $-0.12( \pm 0.01)^{*}$ & $-0.27( \pm 0.02)^{*}$ & $-0.18( \pm 0.001)^{*}$ \\
Total & $-0.23( \pm 0.001)^{*}$ & $-0.34( \pm 0.01)^{*}$ & $-0.20( \pm 0.04)^{*}$ \\
\hline Velox TL & $0.65( \pm 0.01)^{*}$ & $0.39( \pm 0.02)^{*}$ & $0.62( \pm 0.04)^{*}$ \\
Alexandergrass & $-0.31( \pm 0.03)^{*}$ & $-0.27( \pm 0.02)^{*}$ & $-0.18( \pm 0.001)^{*}$ \\
Total & $-0.23( \pm 0.001)^{*}$ & $-0.43( \pm 0.001)^{*}$ & $-0.42( \pm 0.001)^{*}$ \\
& $0.46( \pm 0.03)^{*}$ & $0.31( \pm 0.02 *)$ & $0.39( \pm 0.01)^{*}$ \\
AS 1551 PRO 2 & & $5 h o 0 t d r y ~ m a t t e r$ & $-0.14( \pm 0.001)^{*}$ \\
Alexandergrass & $-0.09( \pm 0.03)$ & $-0.26( \pm 0.06)^{*}$ & $0.93( \pm 0.46)$ \\
Total & $-0.09( \pm 0.04)$ & $0.43( \pm 0.22)$ & $1.79( \pm 0.46)$ \\
\hline MG 300 PW & $0.82( \pm 0.04)^{*}$ & $1.16( \pm 0.19)$ & $-0.04( \pm 0.001)^{*}$ \\
Alexandergrass & $-0.005( \pm 0.05)$ & $-0.07( \pm 0.02)$ & $-0.57( \pm 0.01)^{*}$ \\
Total & $-0.23( \pm 0.001)^{*}$ & $-0.43( \pm 0.001)^{*}$ & $0.39( \pm 0.01)^{*}$ \\
\hline NS 92 PRO & $0.76( \pm 0.05)^{*}$ & $0.50( \pm 0.02)^{*}$ & $-0.07( \pm 0.001)^{*}$ \\
Alexandergrass & $0.11( \pm 0.04)$ & $-0.19( \pm 0.03)^{*}$ & $-0.60( \pm 0.01)^{*}$ \\
Total & $-0.23( \pm 0.001)^{*}$ & $-0.46( \pm 0.001)^{*}$ & $-0.06( \pm 0.001)^{*}$ \\
\hline Velox TL & $0.87( \pm 0.04)$ & $0.35( \pm 0.03)^{*}$ & $-0.23( \pm 0.02)^{*}$ \\
Alexandergrass & $0.14( \pm 0.02)^{*}$ & $0.14( \pm 0.02)^{*}$ & $0.71( \pm 0.02)^{*}$ \\
Total & $-0.21( \pm 0.001)^{*}$ & $-0.42( \pm 0.001)^{*}$ & $0.72( \pm 0.02)^{*}$
\end{tabular}

* Significant difference by the "t" test $(p \leq 0.05)$. Values in parentheses represent the standard error of the average.

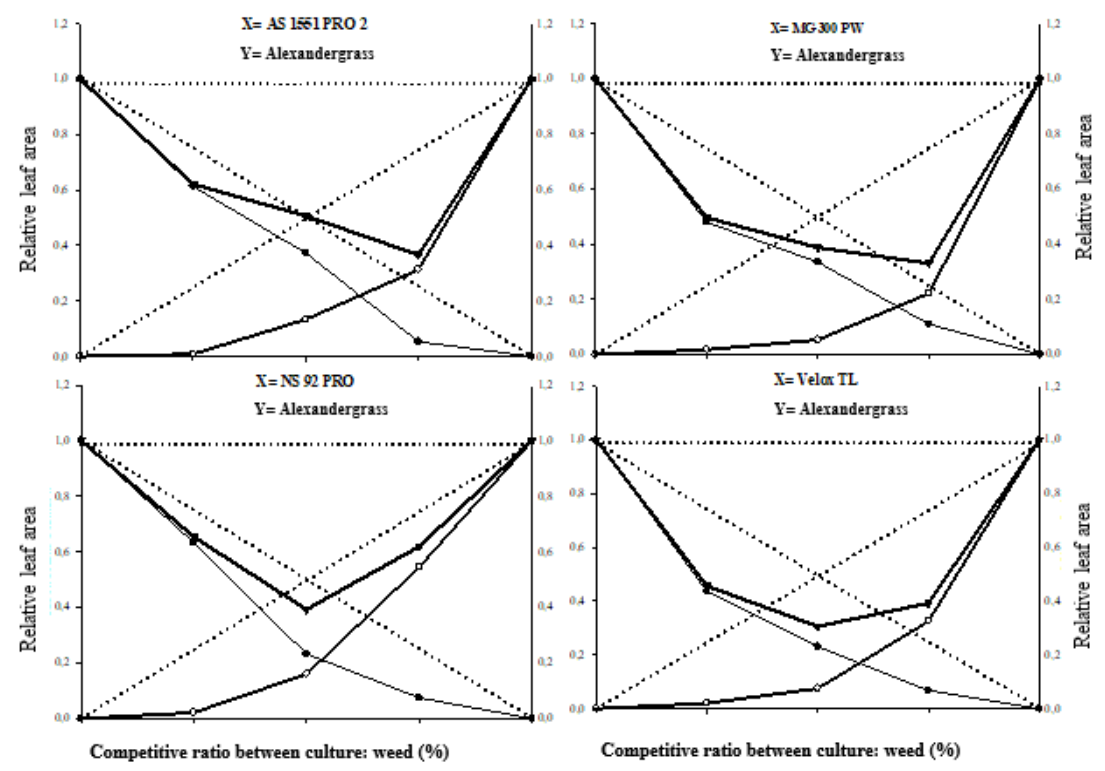

Fig. 1. Relative productivity (RP) for relative leaf area of $\operatorname{corn}(\bullet)$, alexandergrass $(0)$, and total relative productivity (TRP) of the community $(\boldsymbol{\Delta})$ as a function of the proportion of plants (corn: alexandergrass). Dashed lines represent the expected values, in the absence of competition, and solid lines the values observed when the species competed in different proportions of plants 
Table 2. Differences between maize hybrids (Agroeste - AS 1551 PRO 2, Morgan - MG 300 PW, Nidera - NS 92 PRO and Syngenta Velox TL) and alexandergrass (Urochloa plantaginea) for leaf area and dry mass of the shoot part, 50 days after the emergence of the plants.

\begin{tabular}{|c|c|c|c|c|}
\hline \multirow[t]{2}{*}{ Plant proportions } & \multicolumn{4}{|c|}{ Maize hybrids } \\
\hline & AS 1551 PRO 2 & MG 300 PW & NS 92 PRO & Velox TL \\
\hline Maize:alexandergrass & \multicolumn{4}{|c|}{ Leaf area $\left(\mathrm{cm}^{2}\right.$ pot $\left.^{-1}\right)$} \\
\hline $100: 0(T)$ & 2272.74 & 2087.98 & 2522.06 & 2838.09 \\
\hline $75: 25$ & 1858.51 & $1336.51^{*}$ & 2127.61 & $1653.00 *$ \\
\hline $50: 50$ & $1695.50 *$ & $1397.86^{*}$ & 1172.09* & $1311.54 *$ \\
\hline $25: 75$ & $473.78 *$ & $917.22^{*}$ & $747.34^{*}$ & $764.36^{*}$ \\
\hline CV (\%) & 12.77 & 16.10 & 14.21 & 8.93 \\
\hline Alexandergrass:Maize & \multicolumn{4}{|c|}{$\left(\mathrm{cm}^{2} \mathrm{pot}^{-1}\right)$} \\
\hline $100: 0(T)$ & 4347.39 & 1803.87 & 3497.46 & 3730.65 \\
\hline $75: 25$ & 1814.91 & $532.35^{*}$ & $2542.41^{*}$ & $1618.01^{*}$ \\
\hline $50: 50$ & $1160.46^{*}$ & $191.68 *$ & $1119.14^{*}$ & $556.34^{*}$ \\
\hline $25: 75$ & $144.77^{*}$ & $119.91^{*}$ & $295.93^{*}$ & $297.21^{*}$ \\
\hline CV (\%) & 59.81 & 11.17 & 10.31 & 3.37 \\
\hline \multirow[t]{2}{*}{ Plant proportions } & \multicolumn{4}{|c|}{ Maize hybrids } \\
\hline & AS 1551 PRO 2 & MG 300 PW & NS 92 PRO & Velox TL \\
\hline Maize:alexandergrass & \multicolumn{4}{|c|}{ Shoot dry matter $\left(\mathrm{g} \mathrm{pot}^{-1}\right)$} \\
\hline $100: 0(T)$ & 29.46 & 22.97 & 31.56 & 35.32 \\
\hline $75: 25$ & 25.77 & 22.84 & 36.14 & 41.99* \\
\hline $50: 50$ & $13.95^{*}$ & 19.84 & $19.69 *$ & $44.90 *$ \\
\hline $25: 75$ & $13.50 *$ & $19.25^{*}$ & $22.77^{*}$ & $27.79 *$ \\
\hline CV (\%) & 18.18 & 7.39 & 8.69 & 7.16 \\
\hline Alexandergrass:maize & \multicolumn{4}{|c|}{ Shoot dry matter (g pot $\left.{ }^{-1}\right)$} \\
\hline $100: 0(T)$ & 4.85 & 16.97 & 41.13 & 29.89 \\
\hline $75: 25$ & 10.83 & $3.98^{*}$ & $8.39 *$ & $20.48 *$ \\
\hline $50: 50$ & 8.99 & $2.23 *$ & $3.13^{*}$ & $4.99 *$ \\
\hline $25: 75$ & 3.08 & $1.18^{*}$ & $2.65^{*}$ & $4.73^{*}$ \\
\hline CV (\%) & 46.62 & 8.26 & 15.96 & 11.93 \\
\hline
\end{tabular}

* Average differs from control (T) by Dunnett's test $(p<0.05)$.

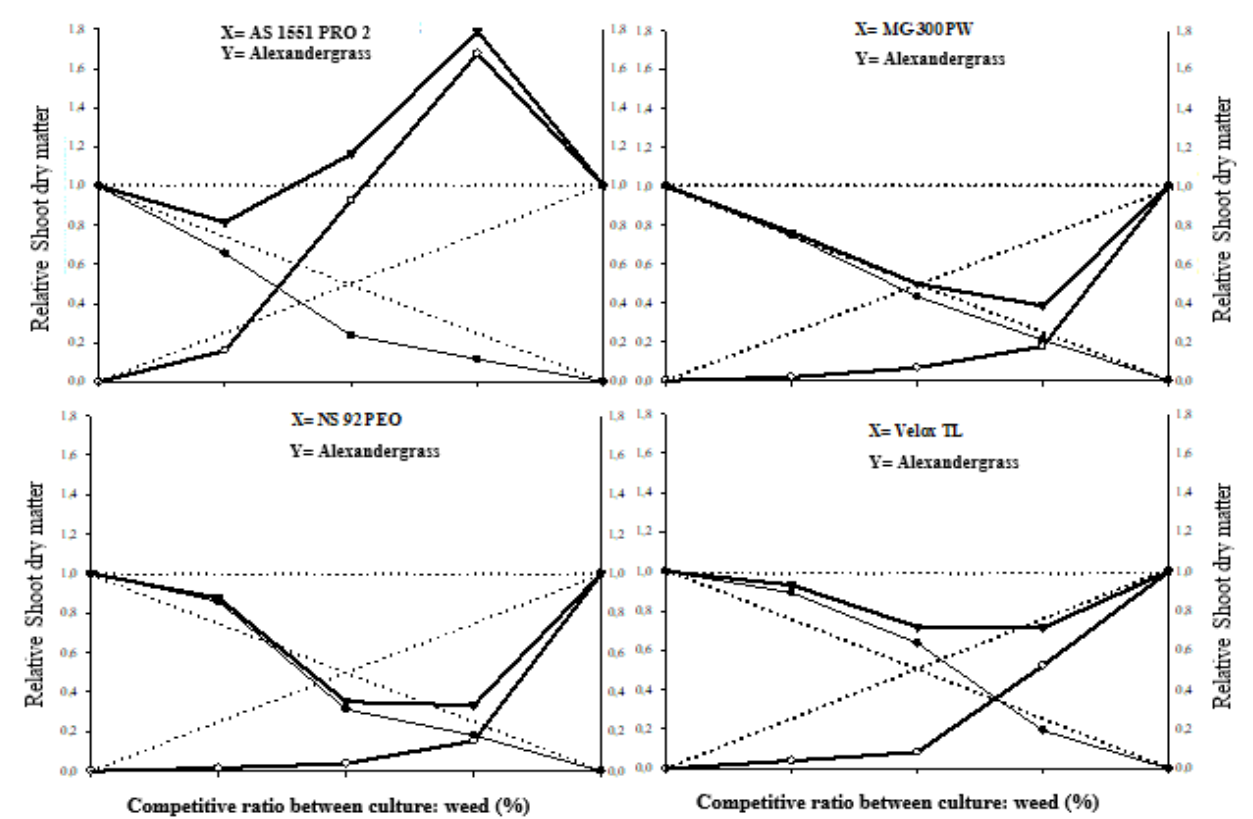

Fig 2. Relative productivity (RP) for relative dry mass of corn $(\bullet)$, alexandergrass $(0)$, and total relative productivity (TRP) of the community $(\mathbf{\Lambda})$ as a function of the proportion of plants (corn: alexandergrass). Dashed lines represent the expected values, in the absence of competition, and solid lines the values observed when the species competed in different proportions of plants. 
Table 3. Competitiveness indexes among maize hybrids (Agroeste - AS 1551 PRO 2, Morgan - MG 300 PW, Nidera - NS 92 PRO and Syngenta - Velox TL) and alexandergrass (Urochloa plantaginea), expressed by relative competitiveness (RC), cluster coefficients relative $(K)$ and aggressiveness $(A)$, obtained in experiments carried out in replacement series, at 50 days after emergence.

\begin{tabular}{lcccc}
\hline \multicolumn{1}{c}{ Variable } & $\mathrm{CR}$ & $\mathrm{K}_{\mathrm{x}}$ & $\mathrm{K}_{\mathrm{y}}$ & $\mathrm{A}$ \\
\hline AS 1551 PRO 2 x alexandergrass & $2.97( \pm 0.46)^{*}$ & $0.60( \pm 0.05)^{*}$ & $0.16( \pm 0.03)^{*}$ & $0.24( \pm 0.01)^{*}$ \\
MG 300 PW x alexandergrass & $6.25( \pm 0.67)^{*}$ & $0.52( \pm 0.1)^{*}$ & $0.06( \pm 0.002)^{*}$ & $0.28( \pm 0.04)^{*}$ \\
NS 92 PRO x alexandergrass & $1.45( \pm 0.10)^{*}$ & $0.30( \pm 0.03)^{*}$ & $0.19( \pm 0.01)^{*}$ & $0.07( \pm 0.02)^{*}$ \\
Velox TL x alexandergrass & $3.10( \pm 0.26)^{*}$ & $0.30( \pm 0.03)^{*}$ & $0.08( \pm 0.001)^{*}$ & $0.16( \pm 0.02)^{*}$ \\
\hline Shoot dry matter & & & & $-0.69( \pm 0.25)$ \\
\hline AS 1551 PRO 2 x alexandergrass & $0.31( \pm 0.15)^{*}$ & $0.33( \pm 0.10)$ & $3.20( \pm 0.5)$ & $0.37( \pm 0.02)^{*}$ \\
MG 300 PW x alexandergrass & $6.56( \pm 0.30)^{*}$ & $0.76( \pm 0.06)^{*}$ & $0.07( \pm 0.0009)^{*}$ & $0.27( \pm 0.03)^{*}$ \\
NS 92 PRO x alexandergrass & $8.49( \pm 1.35)^{*}$ & $0.46( \pm 0.06)^{*}$ & $0.04( \pm 0.005)^{*}$ & $0.55( \pm 0.02)^{*}$ \\
Velox TL x alexandergrass & $7.71( \pm 0.35)^{*}$ & $1.77( \pm 0.18)^{*}$ & $0.09( \pm 0.002)^{*}$ & Leaf area
\end{tabular}

* Significant difference by $\mathrm{t}$-test $(\mathrm{p}<0.05)$. Values in parentheses represent the standard error of the average, $\mathrm{K}_{\mathrm{x}}$ and $\mathrm{K}_{\mathrm{y}}$ are the relative clustering coefficients of the maize hybrids and the alexandergrass competitor, respectively.

Table 4. Genetic characteristics of the hybrids used in the study.

\begin{tabular}{ccll}
\hline Company & Pedigree & Genotype & Cycle and biotechnology \\
\hline Agroeste & AS 1551 PRO2 & Single cross & Early cycle and VT PRO 2 biotechnology \\
Morgan & MG 300 PW & Single cross & Early cycle and Power Core biotechnology \\
Nidera & NS 92 PRO & Single cross & Early cycle and biotechnology VT PRO \\
Syngenta & Velox TL & Single cross & Early cycle and biotechnology TL \\
\hline
\end{tabular}

significance in at least two indices), in relation to alexandergrass in all indexes (CR, $K$ and $A)$. In general, differences between maize hybrids and alexandergrass were observed, which shows that both are not equivalent in terms of competition, emphasizing that the crop is more competitive than the weed (Table 3).

Corroborates with the results of the present study those found by Wandscheer et al. (2014) who also found that maize was more competitive than the Sudan grass. Using the three indexes to define competitiveness, it was observed that sorghum cultivated was more competitive than Sorghum halepense (Hoffman and Buhler, 2002), that soybean cultivars were more competitive than weeds (Forte et al., 2017) and that red rice presented greater aggressiveness than rice (Fleck et al., 2008). According to Vilá et al., (2004) when sowing the crops in association with weeds, with variation in the proportion of plants, the crops usually have an advantage in relation to relative productivity, thus demonstrating that intraspecific competition exceeds interspecific competition. We interpreted the graphs of relative variables and their significance in relation to the equivalent values (Figures 1 and 2, Table 1), the morphological variables (Table 2 ) and the competitiveness indexes (Table 3 ). In general, there was a negative interaction effect among the species, being the maize hybrids Agroeste - AS 1551 PRO 2, Morgan - MG 300 PW, Nidera - NS 92 PRO and Syngenta - Velox TL, as well as the alexandergrass are affected. The maize hybrids, in general, showed a greater competitive ability than the alexandergrass in all proportions of associated plants. Thus, the differences in competitiveness of the evaluated species may be due to the fact that they exploit the same resources, water, light and nutrients. It was found that the unmanaged alexandergrass when infesting the crop will cause losses due to the high competitiveness. Corroborates with the present work the results found by Christoffoleti and Victoria Filho, (1996) and Wandscheer et al. (2014) to denote that competition occurred between maize in the presence of Amaranthus spp. and sudan grass, respectively. Research has reported that species belonging to the same botanical families have similarities in the demand for resources of the environment; sorghum $\times$ Sorghum halepense (Hoffman and Buhler, 2002), rice $x$ rice-red (Fleck et al., 2008) and rice $x$ gulf cockspur grass (Galon and Agostinetto, 2009). Knowledge of the dynamics and competitiveness of plants, especially maize and alexandergrass, is important for decision-

making to control weeds in a given population that will not cause negative interference with the crop, especially considering that the alexandergrass produces seeds in abundance, and that they can remain dormant in the soil for more than a decade (Voll et al., 2001). Skora Neto (2001) found a population of 2000 emerged plants per hectare of alexandergrass, after having performed for 10 years the prevention of seed production in the area.

\section{Materials and Methods}

Nine experiments were carried out in the greenhouse of the Federal University of the Fronteira Sul (UFFS), Campus Erechim, RS, between November 2015 and February 2016. The experimental units were composed of plastic pots with a capacity of $8 \mathrm{dm}^{3}$, filled with soil originating from agricultural area, characterized as Red Latosol (Embrapa, 2013). Correction of $\mathrm{pH}$ and soil fertility was performed according to the technical recommendations for maize cultivation and based on physico-chemical analysis (Rolas, 2004). The chemical and physical characteristics of the soil were: $\mathrm{pH}$ in water de 4.8; Organic matter $=3.5 \% ; \mathrm{P}=4.0 \mathrm{mg} \mathrm{dm}^{-3} ; \mathrm{K}=$ $117.0 \mathrm{mg} \mathrm{dm}^{-3} ; \mathrm{Al}^{3+}=0.6 \mathrm{cmolc} \mathrm{dm}^{-3} ; \mathrm{Ca}^{2+}=4.7 \mathrm{cmolc} \mathrm{dm}^{-3}$; $\mathrm{Mg}^{2+}=1.8$ cmolc $\mathrm{dm}^{-3} ; \quad \mathrm{CEC}(\mathrm{t})=7.4$ cmolc $\mathrm{dm}^{-3}$; $\mathrm{CEC}(\mathrm{TpH}=7.0)=16.5 \mathrm{cmolc} \mathrm{dm}^{-3} ; \mathrm{H}+\mathrm{Al}=9.7 \mathrm{cmolc} \mathrm{dm}^{-3} ; \mathrm{SB}=$ $6.8 \mathrm{cmolc} \mathrm{dm}^{-3} ; \mathrm{V}=41 \%$ and $\mathrm{Clay}=60 \%$.

\section{Plant materials}

The information of the hybrids used is shown in table 4 . Four experiments were carried out to evaluate the competition 
ability of the maize hybrids of Agroeste (AS 1551 PRO 2), Morgan (MG 300 PW) and Nidera (NS 92 PRO) and Syngenta (Velox TL) with alexandergrass plants. Both were conducted in replacement series, in the different combinations of maize hybrids and weed biotype, varying the relative proportions of plants pot ${ }^{-1}$ of: 100: 0, 75:25, 50:50, 25:75 and 0: 100 which was equivalent to 20: $0,15: 5,10: 10,5: 15$ and 0:20 plants pot $^{-1}$ of the species, keeping the total population of plants (20 pot ${ }^{-1}$ plants) constant. To establish the desired populations in each treatment and to obtain uniformity of the seedlings, the seeds were previously seeded in trays and later transplanted to the pots.

\section{Experimental design, installation and conduction of experiments}

The experimental design adopted in all experiments was a randomized block design, with four replications. In a preliminary study, for both maize hybrids and alexander grass, five experiments were carried out in monocultures to estimate the plant population in which the final dry matter production becomes constant. For this, the populations of 1 , $2,4,8,16,24,32,40,48,56$ and 64 plants pot ${ }^{-1}$ (equivalent to $25,49,98,196,392,587,784,980,1,176,1,372$ and 1,568 plants $\mathrm{m}^{-2}$ ). The shoot part of the maize and/or alexandergrass plants were collected 50 days after the emergence of the species to determine the dry matter of the aerial part (DM), which was quantified by weighing, after being dried in a forced circulation oven air at a temperature of $65 \pm 5{ }^{\circ} \mathrm{C}$ until reaching a constant weight. By the average values of DM of the species, there was a constant production of DM with populations of 20 plants pot ${ }^{-1}$, for all maize hybrids and/or alexandergrass biotype, corresponding to 463 $\mathrm{m}^{-2}$ plants (data not shown).

\section{Variables evaluated}

At 50 days after the emergence of the species, the leaf area (LA) and the DM of both maize and the competitor were measured. The determination of LA was performed with a portable $\mathrm{Cl}-203$ BioScence leaf area meter, and the variable was quantified in all plants in each treatment. After the quantification of LA, the shoot part of the plants was conditioned in paper bags and dried in a forced air

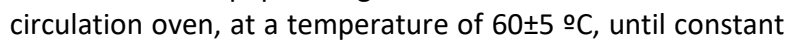
DM was obtained.

\section{Graphical and statistical analyzes}

The data were analyzed using the method of graphical analysis of variation or relative productivity (Radosevich, 1987; Roush et al., 1989; Cousens, 1991; Bianchi et al., 2006). This procedure, also known as the conventional method for replacement experiments, consists of the construction of a diagram based on the relative (RP) and total (TRP) yields or variations. When the RP result is a straight line, it means that the species' abilities are equivalent. If RP results in a concave line, there was damage in the growth of one or both species. On the contrary, if RP results in a convex line, there is a benefit in the growth of one or both species. When the TRP is equal to unit 1 (straight line), competition occurs for the same resources; if it is greater than 1 (convex line), the competition is minimized. If the TRP is less than 1 (concave line), there is mutual impairment to growth (Cousens, 1991).

Relative competitiveness (RC), relative clustering coefficient (K) and aggressiveness (A) of the species were also calculated. The RC represents the comparative growth of maize hybrids $(X)$ relative to the alexandergrass competitor $(\mathrm{Y})$; $\mathrm{K}$ indicates the relative dominance of one species over the other; and A points which species is more aggressive. Thus, the RC, $\mathrm{K}$ and $\mathrm{A}$ indices indicate which species is more competitive and their joint interpretation indicates more safely the species' competitiveness (Cousens, 1991). Hybrids of maize " $X$ " are more competitive than the alexandergrass competitor " $\mathrm{Y}$ " when $\mathrm{CR}>1, \mathrm{~K}_{\mathrm{x}}>\mathrm{K}_{\mathrm{y}}$ and $\mathrm{A}>0$; on the other hand, the Papuan competitor " $Y$ " is more competitive than the " $X$ " maize hybrids when $C R<1, K_{x}<K_{y}$ and $A<0$ (Hoffman; Buhler, 2002). In order to calculate these indexes, the proportions 50:50 of the species involved in the experiment (maize versus alexandergrass), that is, the populations of 10,10 plants pot ${ }^{-1}$ were used, using the following equations: $\mathrm{CR}=\mathrm{PR}_{\mathrm{x}} / \mathrm{PR}_{\mathrm{y}} ; \mathrm{K}_{\mathrm{x}}=\mathrm{PR}_{\mathrm{x}} /\left(1-\mathrm{PR}_{\mathrm{x}}\right) ; \mathrm{K}_{\mathrm{y}}=\mathrm{PR}_{\mathrm{y}} /\left(1-\mathrm{PR}_{\mathrm{y}}\right) ; \mathrm{A}=\mathrm{PR}_{\mathrm{x}}-$ $P R_{y}$, according to Cousens and O'Neill (1993).

The procedure of statistical analysis of productivity or relative variation included the calculation of the differences for the RP (DRP) values obtained in proportions 25, 50 and $75 \%$ in relation to the values belonging to the hypothetical line in the respective proportions, that is, $0.25,0.50$ and 0.75 for RP (Bianchi et al., 2006; Fleck et al., 2008). The t-test was used to test for DRP, TRP, RC, $K$ and $A$ indexes (Roush et al., 1989; Hoffman and Buhler, 2002). It was considered as null hypothesis, to test the differences of DPR and A, that the averages were equal to zero $\left(H_{\circ}=0\right)$; for TRP and $C R$, that the averages were equal to one $(\mathrm{Ho}=1)$; and for $\mathrm{K}$, that the averages of the differences between $\mathrm{K}_{\mathrm{x}}$ and $\mathrm{K}_{\mathrm{y}}$ were equal to zero $\left[\mathrm{H}_{\mathrm{o}}=\left(\mathrm{K}_{\mathrm{x}}-\mathrm{K}_{\mathrm{y}}\right)=0\right]$. The criterion for considering the RP and TRP curves other than the hypothetical lines was that, at least in two proportions, significant differences occurred by the " $t$ " test (Bianchi et al., 2006; Fleck et al., 2008). Likewise, for $C R, K$ and $A$, the existence of differences in competitiveness was considered when, at least in two of them, there was a significant difference by the t test.

The results obtained for both maize and competitor LA and DM, expressed as average values per treatment, were subjected to analysis of variance by the $\mathrm{F}$ test and when this was significant the averages of the treatments were compared by the Dunnett test, considering monocultures as witnesses in these comparisons. In all the statistical analyzes carried out, $p \leq 0,05$.

\section{Conclusion}

The results allow to conclude that competition between the maize hybrids (Agroeste - AS 1551 PRO 2, Morgan - MG 300 PW, Nidera - NS 92 PRO and Syngenta - Velox TL) occurs with the alexandergrass, being negatively affected regardless of the proportion of plants, causing reductions in the LA and DM of the species. Interspecific competition causes less damage to LA and DM of species than intraspecific competition. There is basically competition for the same resources between the maize and the alexandergrass. When comparing the species among themselves, maize was more competitive than the alexandergrass. In high populations of alexandergrass, there is a need for management to avoid the negative effect on maize growth. 


\section{Acknowledgements}

To CNPq, FAPERGS and FINEP for financial support for research and scholarships.

\section{References}

Agostinetto D, Fontana LC, Vargas L, Catarina Markus C, Oliveira E (2013) Relative competitive ability of crabgrass in coexistence with flooded rice and soybean. Pesq Agropec Bras. 48: 1315-1322.

Agostinetto D, Rigoli RP, Galon L, Moraes PVDM, Fontana LC (2009) Relative competitiveness of soybean in simultaneous growth with alexandergrass (Brachiaria plantaginea). Sci Agr. 10:185-90.

Almeida LA, Mundstock CM (2001) Light quality affects tillering on wheat when grown under competition. Cienc Rural. 31: 401-408.

Bianchi MA, Fleck NG, Lamego FP (2006) Proportion among soybean and competitor plants and the relations of mutual interference. Cienc Rural. 36: 1380-1387.

Brito AH, Pinho RG von, Santos AO, Santos S (2011) Reaction of commercial maize hybrids and comparison of methods for evaluation of maize white spot and gray leaf spot. Trop Plant Path. 36: 35-41.

Christoffoleti PJ, Victória Filho R (1996) Density and porportion effects among maize (Zea mays L.) and pigweed (Amaranthus retroflexus L.) under competition. Planta Daninha. 14:42-47.

Conab - Companhia Nacional de Abastecimento. Acompanhamento da safra brasileira, V. 5 - Safra 2017/18$\mathrm{N}^{\circ} 4$ - Quarto levantamento - janeiro de 2018. [Acesso em 05 de fev de 2018]. Disponível em: http://www.conab.gov.br/arquivos/18_01_11_14_17_49_ graos_4o_levantamento.pdf.

Costa LO, Rizzardi MA (2015) Competitive ability of wheat in association with biotypes of Raphanus raphanistrum L. resistant and susceptible to ALS-inhibitor herbicides. Ciênc e agrotec. 39: 121-130.

Cousens R, O'Neill M (1993) Density dependence of replacement series experiments. Oikos. 66: 347-352.

Cousens R (1991) Aspects of the design and interpretation of competition (interference) experiments. Weed Tecnol. 5: 664-673.

Dias-Filho MB (2006) Competição e sucessão vegetal em pastagens. Embrapa Amazônia Oriental. Versão Eletrônica: 38.

Embrapa - Empresa brasileira de pesquisa agropecuária (2013) Sistema brasileiro de classificação de solos. Embrapa Solos. 154p.

Faria RM, Barros RE, Tuffi Santos LD (2014) Weed interference on growth and yield of transgenic maize. Planta Daninha. 32: 515-520.

Ferreira EA, Silva AA, Reis MR, Santos JB, Oliveira JA, Vargas L, Khouri KR, Guimarães AA (2008) Glyphosate distribution and nutrient accumulation in ryegrass biotypes. Planta Daninha. 26: 165-173.

Fleck NG, Lazaroto CA, Schaedler CE, Ferreira FB (2008) Susceptibility of three joint vetch species (Aeschynomene spp.) to herbicides used in postemergence in flooded rice. R Bras Agrociência. 14: 462-470.

Forte CT, Basso FJM, Leandro Galon L, Agazzi LR, Nonemacher F, Concenço G (2017) Competitive ability of transgenic soybean cultivars coexisting with weeds.

Agrária. 12: 185-193.

Galon L, Agostinetto D (2009) Comparison of empirical models for predicting yield loss of irrigated rice (Oryza sativa) mixed with Echinochloa spp. Crop Protection. 28: 825-830.

Galon L, Tironi SP, Rocha PRR, Concenço G, Silva AF, Vargas L, Silva AA, Ferreira EA,Minella E, Soares ER, Ferreira FA (2011) Competitive ability of barley cultivars against ryegrass. Planta Daninha. 29: 771-781.

Hoffman ML, Buhler DD (2002) Utilizing Sorghum as a functional model of crop weed competition. I. Establishing a competitive hierarchy. Weed Sci. 50: 466-472.

Jannink JL, Orf JH, Jordan NR, Shaw RG (2000) Index selection for weed suppressive ability in soybean. Crop Sci. 40: 1087-1094.

Kissmann KG, Groth D (1999) Plantas infestantes e nocivas. 2nd edn. BASF, São Paulo.

Monquero PA, Hirata ACS, Pitelli RA (2014) Métodos de levantamento da colonização de plantas daninhas. In: Monquero P.A. Aspectos da biologia e manejo das plantas daninhas. São Carlos: RiMa, 2014. p 27-103.

Moraes PVD, Agostinetto D, Vignolo GK, Santos LS, Panozzo LE (2013) Cover crop management and weed control in maize. Semina. Ciênc Agrár. 34: 497-508.

Pantone DJ, Bake RJB (1991) Reciprocal yield analysis of red rice (Oryza sativa) competition in cultivated rice. Weed Sci. 39: 42-47.

Radosevich SR (1987) Methods to study interactions among crops and weeds. Weed Technol. 1: 190-198.

Rigoli RP, Agostinetto D, Schaedler CE, Dal Magro T, Tironi S (2008) Relative competitive ability of wheat (Triticum aestivum) intercropped with Italian ryegrass (Lolium multiflorum) or wild radish (Raphanus raphanistrum). Planta Daninha. 26: 93-100.

ROLAS - Rede Oficial de Análise de Solo e de Tecido Vegetal (2004) Manual de adubação e calagem para os estados do Rio Grande do Sul e Santa Catarina. Porto Alegre: Soc Brasil Ciênc Solo, p.400.

Roush ML, Radosevich SR, Wagner RG, Maxwell BD, Petersen TD (1989) A comparison of methods for measuring effects of density and proporcion in plant competition experiments. Weed Sci. 37: 268- 275.

Rubin RS, Langaro AC, Mariani F, Agostinetto D, Berto RM (2014) Relative competitive ability of irrigated rice with red rice susceptible or resistant to the herbicide imazapyr + imazapic. Arq Instit Biol. 81: 173-179.

Skora Neto F (2001) Effect of weed seed production prevention and 10-year herbicide direct spray on weed density in maize during sucessive years. Planta Daninha. 19: 1-10.

USDA- United States Department of Agriculture. World Agric Cult Produc. [Acesso em 05 de fev de 2018]. Disponível em:

https://www.usda.gov/oce/commodity/wasde/latest.pdf.

Velho GF, Crusciol CAC, Velini ED, Castro GSA, Borghi E (2012) Weed competition between Brachiaria plantaginea and rice culture, cv. 'Primavera'. Planta Daninha. 30: 1726.

Vida FBP, Laca EA, Mackill DJ, Fernández GM, Fischer AJ (2006) Relating rice traits to weed competitiveness and yield: a path analysis. Weed Sci. 54: 1122-1131. 
Vidal RA, Merotto Jr (2010) A. Inicialismo. In: Vidal R (Ed). Interação negativa entre plantas: inicialismo, alelopatia e competição. Porto Alegre: Evangraf, 33-49.

Vilá M, Williamson M, Lonsdale M (2004) Competition experiments on alien weeds with crops: Lessons for measuring plant invasion impact?. Biological Invasions. 6: 59-69.

Voll E, Torres E, Brighenti AM, Gazziero DLP (2001) Dinâmica do banco de sementes de plantas daninhas sob diferentes manejos de solo. Planta Daninha. 19: 171-178.

Wandscheer ACD, Rizzardi MA (2013) Interference of soybean and maize with Chloris distichophylla. Ciênc and Agrotec. 37: 306-312.
Wandscheer ACD, Rizzardi MA, Reichert M, Gaviraghi F (2014) Capacidade competitiva da cultura do milho em relação ao capim-sudão. Rev Bras de Milho Sorgo. 13: 129141.

Wang C, Guo G, Li Y, Wang Z (2018) Systematic comparison of C3 and C4 plants based on metabolic network analysis. BMC Systems Biology. 6: 1-14.

Wu W, Fan L, Maofen L, Hongbin L, Yaoqin L (2012) Sensitivity analysis of crop growth models to multitemporal scale solar radiation. Trans Chin Soc Agricult Eng. 28: 123-128.

Zanine AM, Santos EM (2004) Competition among species of plants - A review. Rev Fac Zootec Vet Agr. 11: 10-30. 